\title{
The Influence of Intellectual Ability, Discipline and Work Motivation on Teacher Performance in Senior High School (SMAN) 1 Karang Baru Aceh, Tamiang Regency
}

\author{
Tengku Muhammad Sahudra \\ University of Samudra, Langsa-Aceh, Indonesia \\ Tengkusahudra@unsam.ac.id
}

\begin{abstract}
The formulation of the problem in this study is how the influence of intellectual ability on teacher performance in Senior High School 1 of Karang Baru, Aceh Tamiang Regency. How is the influence of discipline on teacher performance in Senior High School 1 of Karang Baru, Aceh Tamiang Regency. What is the influence of work motivation on teacher performance in Senior High School 1 of Karang Baru, Aceh Tamiang Regency. How is the influence of intellectual ability, discipline and work motivation on teacher performance in Senior High School 1 of Karang Baru, Aceh Tamiang Regency. The purpose of this study was to determine the effect of intellectual ability on teacher performance. To determine the effect of discipline on teacher performance. To determine the effect of work motivation on teacher performance. To determine the effect of intellectual ability, discipline and work motivation on teacher performance. The sample in this study amounted to 50 teachers. The data analysis technique used is multiple linear regression analysis. The results of this study are intellectual ability, discipline and work motivation simultaneously have a positive and significant effect on teacher performance Senior High School 1 of Karang Baru, Aceh Tamiang Regency because the value of $F$ count $>$ Ftable is (53,510> 2,960). Partial intellectual ability has a positive and significant effect on teacher performance in Senior High School 1 of Karang Baru, Aceh Tamiang Regency because of the tcount> t table (2,918> 1,680). Partial discipline has a positive and significant effect on teacher performance Senior High School 1 of Karang Baru, Aceh Tamiang Regency because of tcount> ttable (8,991>1,680). Partial work motivation has a positive and significant effect on teacher performance Senior High School 1 of Karang Baru, Aceh Tamiang Regency because of the tcount > ttable (2,918> 1,680). Intellectual ability, discipline and work motivation simultaneously influence the performance of teachers in Senior High School 1 of Karang Baru, Aceh Tamiang Regency at $76.30 \%$ and the remaining $32.70 \%$ influenced by other factors not examined.
\end{abstract}

Keywords : intellectual ability; discipline; work motivation; teacher performance.

\section{Introduction}

Competition in various sectors makes the management process, and maintenance of organizational management increasingly gets serious attention from all elements in the organization to create a strong managerial system that is able to keep up with current developments. Human resources in this case the teacher in an educational institution which in this case is the Karang Baru State High School (SMA), of course trying to work in their abilities in order to achieve the satisfaction of the desired teacher's task. The more aspects of the work that are in accordance with the wishes of the teacher, the higher the level of satisfaction the task feels.

A sense of security in the work atmosphere that is able to encourage teachers to be more dedicated in completing the tasks given by the leadership both in a safe atmosphere before work, at work or after work. This kind of safe working conditions, and supported by colleagues who can be invited to cooperate in various activities is the desire of each individual in an 
educational institution. With such a situation it is expected that the teachers can work optimally and be happy with the work they do. On the other hand, individual needs in fulfilling their desires are increasing. The teachers work in the hope that they will get a salary / salary that can meet those needs. Current needs are very complex from the most basic / primary things, especially the problem of clothing, food, housing, education, adequate work rest, need to get the top priority scale in terms of fulfillment. In addition, fulfilling the needs of the teachers for service and respect by superiors for the work performance they produce that is in accordance with the principles of justice can motivate their work.

Based on preliminary observations, the authors suspect that the teacher's performance is determined by the intellectual ability, discipline and work motivation of each teacher. Intellectual ability is a number of basic abilities owned by someone and is used to solve problems both experienced by oneself and in the environment. While work motivation is a driving force for a teacher to do something in achieving goals. The higher the intellectual ability and motivation of one's work, the higher the performance, and vice versa.

There are several phenomena or problems that researchers can observe in these schools, including teachers who are basically not fully able to say the category of professional teachers and contributions to students become less noticeable even neglected. Another problem found by the author is that there are still teachers who are late and go home too fast, the teacher's education qualifications for teaching are not in accordance with their expertise. So that the impact is that students as students do not get maximum learning outcomes.

\section{Review of Literature}

The strategic position of the teacher is then needed through the performance of the teacher. Teacher's performance in the teaching and learning process is essentially the role of the teacher in accordance with his responsibilities and duties. Peters presents the duties and responsibilities of the teacher, namely (1) the teacher as the teacher, (2) the teacher as the guide and (3) the teacher as the class administration. While Peters, Armstrong divides tasks and responsibilities into five categories, namely (1) Responsibility in teaching; (2) Responsibility in providing guidance; (3) Responsibility for developing the curriculum; (4) Responsibility in developing achievement and (5) Responsibility in fostering the community. (Sudjana, 2004: 15). With regard to the performance of teachers as instructors, according to Usman (2005: 16), it covers aspects of personal abilities, professional abilities and social abilities.

August W. Smith states that performance is "...... output drive from processes, human or otherwise", so performance is the result or output of a process. (Sedarmayanti, 2001: 50). Whereas according to Mathis (2002: 78), reveals that performance is basically what the teacher does or does not do. Besides that Mitchell (1978), states that performance covers several aspects, namely quality of work, promptness, initiative, capability and communication.

According to Robbins (2001: 46) intellectual ability is the mental ability needed to carry out mental activities. Whereas Tilaar (2002: 238), the teacher's intellectual ability is a variety of knowledge tools that exist within the individual that are needed to support various aspects of performance as a teacher.

The education is quality when giving birth to graduates who have pragmatic practical abilities, are productive and can do jobs that provide economic and social benefits (Danim, 2003: 192). In realizing quality education and quality learning not only depends on a component, but all components, which include students, materials, media, facilities and 
infrastructure, curriculum and costs / funds. However, all components of education cannot be optimally utilized for improving the quality of learning processes and outcomes without being supported by the existence of teachers who continuously strive to realize ideas, ideas and thoughts in the form of superior behavior and attitudes in their duties as educators. A teacher should be able to build a conducive learning atmosphere in teaching and learning activities to achieve the stated goals. Because the teaching and learning process is seen as a position where the estuary of all teacher performance is accommodated in it.

The teacher is a condition that is positioned as the front guard in the implementation of the teaching and learning process and the teacher holds a very strategic position in an effort to create professional and quality graduates so as to meet professional human resource needs. In line with Adler's opinion, the teacher is also a human element that greatly determines the success of education (Bafadal, 2002: 24).

A teacher in carrying out his/her duties and responsibilities needs to be supported by optimal performance, because the teacher is the main component in determining the success of learning. Teacher performance (performance) is a function of the interaction between ability and motivation (Robbins, 2001: 218). Teacher performance is the result of work or work performance carried out by a teacher based on his ability to manage teaching and learning activities. In this case the teacher's performance can be seen through his appearance in the teaching and learning process starting from the opening to the closing of the lesson. A teacher in carrying out his duties and responsibilities, besides having high intellectual abilities, is also required to have high work motivation. Logically a person who has high intellectual abilities and is supported by high motivation will produce high performance, and conversely people who have low intellectual abilities and low motivation will produce low performance as well.

Thus the teacher's performance greatly determines the success of an effective and efficient teaching and learning process so that educational goals can be achieved and materialized from good student achievement.

\section{Research Method}

The population of this study were all teachers in Senior High School 1 Karang Baru of Aceh Tamiang Regency. There were 50 people. In order to obtain a representative sample, the sampling technique in this study used total sampling because the population was considered homogeneous, so the sample in this study was 50 people. teacher at Senior High School 1 Karang Baru,

The data analysis technique used in this study is Multiple Regression Analysis. This analysis technique begun with the preparation of data, namely the tabulation process of data and then the data to facilitate the researcher, the data will be processed using the SPSS Version 20.00 program. Furthermore, data analysis to see the relationship between intellectual ability and work motivation as independent variables on teacher performance as the dependent variable, the researcher uses multiple linear analysis formulas, namely: $\mathrm{Y}=\mathrm{a}+\mathrm{b} 1 \mathrm{X} 1+\mathrm{b} 2 \mathrm{X} 2$ $+\mathrm{b} 3 \mathrm{X} 3+\mathrm{E}$. 


\section{Result and Discussion}

\subsection{Effect of Intellectual Ability on Teacher Performance}

\begin{tabular}{|l|l|r|r|r|r|r|}
\hline \multirow{2}{*}{ Model } & & \multicolumn{2}{|c|}{$\begin{array}{c}\text { Unstandardized } \\
\text { Coefficients }\end{array}$} & $\begin{array}{c}\text { Standardized } \\
\text { Coefficients }\end{array}$ & \multirow{2}{*}{ Sig. } \\
\cline { 3 - 6 } & & \multicolumn{1}{|c|}{ B } & \multicolumn{1}{c|}{$\begin{array}{c}\text { Std. } \\
\text { Error }\end{array}$} & \multicolumn{1}{c|}{ Beta } & t & Sig. \\
\hline 1 & (Constant) & 14.913 & 3.095 & & 4.819 & .000 \\
\hline & $\begin{array}{l}\text { Intellectual } \\
\text { Ability }\end{array}$ & .161 & .055 & .214 & 2.918 & .005 \\
\hline
\end{tabular}

From the picture above it is known that the value of thitung $>$ ttabel $(2,918>1,680)$ then it is decided that the significant regression coefficient or $\mathrm{H}_{0}$ is rejected and accepts the hypothesis in this study, namely the variable intellectual ability partially has a positive and significant effect on teacher performance in Senior High School 1 Karang Baru of Aceh Tamiang Regency. This can also be proven from the Probability value $=0.005$; or $\mathrm{P}<0.05$; means that the regression coefficient of intellectual ability is partially significant at the $95 \%$ confidence level $(\alpha: 0.05)$.

\subsection{Influence of Discipline on Teacher Performance}

\begin{tabular}{|c|c|c|c|c|c|c|}
\hline \multirow[b]{2}{*}{ Model } & & \multicolumn{2}{|c|}{$\begin{array}{l}\text { Unstandardized } \\
\text { Coefficients }\end{array}$} & \multirow{2}{*}{$\begin{array}{c}\text { Standardized } \\
\text { Coefficients } \\
\text { Beta }\end{array}$} & \multirow[b]{2}{*}{$\mathrm{t}$} & \multirow[b]{2}{*}{ Sig. } \\
\hline & & B & $\begin{array}{l}\text { Std. } \\
\text { Error }\end{array}$ & & & \\
\hline 1 & (Constant) & 14.913 & 3.095 & & 4.819 & .000 \\
\hline & Discipline & .388 & .043 & .701 & 8.991 & .000 \\
\hline
\end{tabular}

From the picture above it is known that the value of thitung $>$ ttabel $(8,991>1,680)$ then it is decided that the significant regression coefficient or $\mathrm{H}_{0}$ is rejected and accepts the hypothesis in this study that partially disciplined variables have a positive and significant effect on teacher performance at Senior High School 1 Karang Baru of Aceh Tamiang Regency. This can also be proven from the Probability value $=0,000$; or $\mathrm{P}<0.05$; means that the discipline regression coefficient is partially significant at the $95 \%$ confidence level $(\alpha: 0.05)$.

\subsection{Effect of Motivation on Teacher Performance}

\begin{tabular}{|c|c|c|c|c|c|c|}
\hline \multirow[b]{2}{*}{ Model } & & \multicolumn{2}{|c|}{$\begin{array}{c}\text { Unstandardized } \\
\text { Coefficients }\end{array}$} & \multirow{2}{*}{$\begin{array}{c}\text { Standardized } \\
\text { Coefficients } \\
\text { Beta }\end{array}$} & \multirow[b]{2}{*}{$\mathrm{t}$} & \multirow[b]{2}{*}{ Sig. } \\
\hline & & B & $\begin{array}{l}\text { Std. } \\
\text { Error }\end{array}$ & & & \\
\hline 1 & (Constant) & 14.913 & 3.095 & & 4.819 & .000 \\
\hline & $\begin{array}{l}\text { Work } \\
\text { Motivation }\end{array}$ & .184 & .063 & .238 & 2.918 & .005 \\
\hline
\end{tabular}

From the picture above it is known that the value of thitung $>$ ttabel $(2,918>1,680)$ then it is decided that the significant regression coefficient or $\mathrm{H}_{0}$ is rejected and accepts the hypothesis in this study that the work motivation variable partially has a positive and significant effect on 
teacher performance in High School 1 Karang Baru of Aceh Tamiang Regency. This can also be proven from the Probability value $=0.005$; or $\mathrm{P}<0.05$; means that the work motivation motivation coefficient is partially significant at the $95 \%$ confidence level $(\alpha: 0.05)$.

\begin{tabular}{|c|c|c|c|c|c|c|c|}
\hline \multirow[b]{2}{*}{ Model } & \multirow[b]{2}{*}{$\mathrm{R}$} & \multirow[b]{2}{*}{ R Square } & \multirow{2}{*}{$\begin{array}{l}\text { Adjusted } \\
\text { R Square }\end{array}$} & \multirow{2}{*}{$\begin{array}{l}\text { Std. Error } \\
\text { of the } \\
\text { Estimate }\end{array}$} & \multicolumn{3}{|c|}{ Change Statistic } \\
\hline & & & & & $\begin{array}{c}\mathrm{F} \\
\text { Change }\end{array}$ & df1 & df2 \\
\hline 1 & $.882^{\mathrm{a}}$ & .777 & .763 & 1.01773 & .777 & 53.510 & 3 \\
\hline
\end{tabular}

From the table above it is known that the simultaneous correlation between intellectual ability, discipline and work motivation on teacher performance is 0.777 . This correlation value can be categorized as a strong correlation because it is in the interval $(0.60-0.79)$. then to prove the truth of the research hypothesis or whether the correlation value can be generalized, the significance must be tested by the F-test, and from data processing it is known that the calculated $\mathrm{F}$ value is 53,510 . This $\mathrm{F}$-count value is then interpreted with a Ftable value and a $95 \%$ confidence level $(\alpha=0.05)$, with a numerator $=\mathrm{k}$ and a denominator $=50-3=47$, then the value of Ftable $=2.960$. So from the results of a significant test calculation, it can be seen that the value of Fcount> Ftable is 53,510> 2,960, so the research hypothesis can be simultaneously proven that there is a positive and significant influence between intellectual ability, discipline and work motivation on teacher performance High School 1 Karang Baru of Aceh Tamiang Regency.

Next to find out how much influence intellectual ability, discipline and work motivation on teacher performance in High School 1 Karang Baru of Aceh Tamiang Regency, it was tested by determinant (D) test. From the processing of the data obtained $r^{2}$ (Adjusted Rsquare) value of 0.763 , it can be seen that the Determinant value is $0.763 \times 100 \%=76.30 \%$, which means that the variables of intellectual ability, discipline and work motivation simultaneously influence the performance of teachers in Public High Schools 1 Karang Baru Aceh Tamiang Regency is $76.30 \%$, and the remaining $23.70 \%$ is influenced by other factors not examined.

\section{Conclusion}

In this research we can conclude (1) Intellectual ability, discipline and work motivation simultaneously have a positive and significant effect on teacher performance in in High School 1 Karang Baru of Aceh Tamiang Regency. (2) Partial intellectual abilities have a positive and significant effect on performance teacher in High School 1 Karang Baru of Aceh Tamiang Regency because (3) Partial discipline has a positive and significant effect on teacher performance in High School 1 Karang Baru of Aceh Tamiang Regency (4) Partial work motivation has a positive and significant effect on teacher in High School 1 Karang Baru of Aceh Tamiang Regency (5) Intellectual ability, discipline and work motivation simultaneously influence the performance of teachers in High School 1 Karang Baru of Aceh Tamiang Regency at $76.30 \%$ and the remaining $32.70 \%$ influenced by other factors not examined.

\section{References}

Algifari. 2000. Analisis Regresi : Teori, Kasus dan Solusi. Yogyakarta : BPFE. Amirullah, dan Hanafi, Rindyah. 2002. Pengantar Manajemen. Yogyakarta : Graha Ilmu. 
Anoraga, Panji. 2008. Psiklogi Kerja. Jakarta : PT. Rineka Cipta.

Arikunto, Suharsimi. 2002. Prosedur Penelitian Suatu Pendekatan Praktek. Jakarta : Pt. Rhineka. Cipta.

Bafadal, Ibrahim. 2003. Peningkatan Profesionalisme Guru Sekolah Dasar. Jakarta. PT. Rineka Cipta

Danim, Sudarman. 2003. Agenda Pembaharuan Sistem Pendidikan. Jakarta : Pustaka Belajar.

Depdikbud. 2000. Kamus Besar Bahasa Indonesia. Jakarta : Balai Pustaka.

Fattah, Nanang. 2003. Landasan Kependidikan. Bandung : PT. Remaja Rodaskarya.

Gardener, Howard. 2004. Teori Inteligensi Ganda dan Aplikasinya Di Sekolah. Yogyakarta : Kanisius.

Garis-garis Besar Program Pendidikan dan Pelatihan Produktif. 2009. Jakarta. Departemen Pendidikan dan Kebudayaan.

Hamalik, Umar. 2004. Kurikulum dan Pembelajaran. Bandung : Bumi Aksara.

Hasibuan, Melayu SP. 2003. Organisasi dan Motivasi. Jakarta : PT. Bumi Aksara.

Mathis, Robert L dan Jackson, Jhon H. 2002. Manajemen SDM. Jakarta : Salemba Empat.

Munzert. Alfrend W. 2000. Tes IQ. Jakarta : Ketindo.

Nazir, Moh. 2009. Metode Penelitian. Jakarta : Ghalia Putra.

Purwanto, Ngalim. 2003. Psikologi Pendidikan. Bandung : PT. Remaja Rosdakarya.

Riduwan. 2003. Skala Pengukuran Variabel-variabel Penelitian. Bandung : Alfabeta.

Robbins, Stephen P. 2001. Perilaku Organisasi Jilid I. Yogyakarta : Aditya Media.

Sadarmayanti. 2001. SDM dan Produktivitas Kerja, Bandung : Mandar Maju.

Siswanto, Bedjo. 2000. Manajemen Modern (Konsep dan Aplikasi. Bandung : Sinar Biru.

Soekartawi. 2005. Meningkatkan Efektivitas Mengajar. Jakarta : PT Dunia Pustaka Jaya.

Soeparwoto, dkk. 2005. Psikologi Perkembangan. Semarang. UPT MKK UNNES.

Standar Kompetensi Guru Sekolah Menegah Atas. 2004. Jakarta. Depdiknas.

Sudjana. 2002. Metode Statistik. Bandung : Transito.

Sudjana, Nana. 2004. Dasar-dasar Proses Belajar Mengajar. Bandung : Sinar Baru Algensindo. Sunarto dan Hartono Agung. 2008. Perkembangan peserta Didik. Jakarta : PT Rineka Cipta. Suparno, Paul. 2003. Guru Demokrasi Di Era Reformasi Pendidikan. Jakarta : PT Gramedia. Supeno, Hadi. 2005. Potret Guru. Jakarta. Pustaka Sinar Harapan.

Tilaar, H A R. 2002. Pendidikan Untuk Masyarakat Indonesia Baru. Jakarta : Grasindo.

Moh Usman. 2005. Menjadi Guru Profesional. Bandung : PT Remaja Rosdakarya.

Winardi. 2002. Motivasi dan Permotivasian Dalam Manajemen. Jakarta : PT Raja Grafindo Persada. 